\title{
Criminal Justice Majors' Basic Knowledge of U.S. Constitutional Rights and Pedagogical Implications
}

\author{
Janet Heuer ${ }^{1}$, J.D. \& Porter E. Coggins ${ }^{2}$, III Ph.D. \\ ${ }^{1}$ Department of Criminal Justice, Box \#35, Bemidji State University, 1500 Birchmont DR NE, Bemidji, MN 56601, \\ USA \\ ${ }^{2}$ Department of Professional Education, Box \#35, Bemidji State University, 1500 Birchmont DR NE, Bemidji, MN \\ 56601, USA
}

Correspondence: Janet Heuer, J.D., Department of Criminal Justice, Box \#35, Bemidji State University, 1500 Birchmont DR NE, Bemidji, MN 56601, USA

Received: June 14, 2017

Accepted: July 16, 2017

Online Published: July 25, 2017

doi:10.5430/ijhe.v6n4p79

URL: https://doi.org/10.5430/ijhe.v6n4p79

\begin{abstract}
Criminal justice students preparing at the university level will be required to possess knowledge and understanding of applicable constitutional law, rights and responsibilities upon entering their profession to ensure the competent execution of the duties of which they will be entrusted to perform. Students majoring in the criminal justice field of scholarship at one university situated in the Great Lakes region of the United States participated in this study by completing a pre-instruction and post-instruction questionnaire designed to measure their confidence of Amendments I, IV, X, XIV, and XV of the U.S. Constitution. The intent of this study was to provide a mechanism in which to assess student understanding of basic ideas and examples of each of the amendments. The outcome of the survey study is to provide insight to the effectiveness of instructional pedagogy in a scholarship of teaching framework for undergraduate students majoring in criminal justice. The students participating this this survey were criminal justice majors and were surveyed over four academic semesters spanning two years. The results indicate a significant difference $(\mathrm{p}<.001)$ between pre-survey and post-survey questionnaire aggregate scores at the alpha $=.05$ level with a moderate effect size of .45. Individual pre-survey and post-survey questionnaire scores on confidence of individual amendments were also all significant at the alpha $=.05$ level but with small effect sizes. Implications of small effect sizes are interpreted with respect to program and pedagogical implications.
\end{abstract}

Keywords: Undergraduate, American constitutional amendments, Pedagogy, Scholarship of teaching, Criminal justice education

\section{Introduction}

\subsection{Introduce the Problem}

Do citizens of the United States really understand their constitutional rights under the Bill of Rights? Average Americans, (those without specific legal training) are inundated with legal "advice" through various mediums, including, but not limited to, television sitcoms, reality television, newspapers, television news, internet sources, etc., conversely, and with the exception of perhaps portions of required courses in middle or high school, most Americans have little personal experience and/or have not developed an understanding of the rights afforded under the United State Constitution, specifically the Bill of Rights (the first Ten Amendments of the United States Constitution). This lack of knowledge and understanding commonly results in perpetuating misinformation. Further, some professions must have a basic grounding in constitutional rights for the protection of clients they are entrusted to serve while executing the duties and responsibilities of their respective profession. For example, those working in fields obviously tied to the legal system such as criminal justice (law enforcement, corrections, etc.), wildlife management, and to some extent even teacher education require varying degrees of competence regarding the limits of constitutional rights. In particular, it is important for professors teaching criminal justice courses at institutions of higher education to provide meaningful information to close the gap relative to misinformation acquired up to the point of study at the university level.

Other than three studies in education (Call \& O'Brien 2011; Coggins \& Heuer, forthcoming; and Pell 1994) there has been no scholarly research published regarding the topic of criminal justice majors' knowledge, understanding and 
the ability to articulate and apply basic constitutional rights. An additional purpose of this article will address the pedagogical implications presented in teaching students at institutions of higher education. Because the failure of having knowledge, a solid understanding and ability to articulate and apply the rights afforded under the United States Constitution when students enter their respective professions in the criminal justice system could result in serious repercussions affecting them as individual professionals, the agencies which employ them and to society in general. We conducted this study to fill the gap in the literature on a sample of this population of American students studying criminal justice at a public university situated in the Great Lakes Region of the United States. There is a significant need to fill in this gap considering the increasingly contentions political environment and shifting societal values in which criminal justice majors will find themselves in their career paths. The research presented here discusses what is known about the confidence one sample of American criminal justice undergraduate students have relative to this topic. We did not analyze the amendments or related court decisions because such review is outside the scope of this study. However, we did consider what our students knew about the First, Fourth, Tenth, Fourteenth and Fifteenth Amendments with respect to their confidence to articulate their understanding by providing relevant examples in their anticipated future workplace environment.

It is important to note that at this public university, although offered as an elective in fulfilling general/liberal education requirements, students are not required to complete a course in constitutional law as part of their academic curriculum. However, constitutional law is included as a part of the curriculum in each of the law based courses required in the criminal justice major at this public university.

A few students studying at this university may have some degree of knowledge of the criminal justice system resulting from their observations and/or experiences, however, a limited number of students have direct academic or real exposure to these amendments prior to enrolling and completing coursework associated with the criminal justice field of study at the undergraduate level.

Because the obligations, duties and responsibilities entrusted to professionals working in the criminal justice field are unique to this group of professionals, some of the consequential risks associated with violating the constitutional rights of those whom these professionals have contact is protracted litigation of which would have a tremendous effect on their agency (employer), community as well as a negative effect on the credibility of the individual professional moving forward in their career. The profound effect on the offended individual(s) affected by the violation is also at issue.

The desired goal of this research is to help fill a void in the literature with an up-to-date report relative to the understanding of a sample of undergraduate students majoring in criminal justices and to provide insightful information to faculty teaching in criminal justice departments/programs to ensure students are prepared when entering their respective criminal justice professions.

\subsection{Explore Importance of the Problem}

Because there has been little research published regarding the topic of criminal justice majors' knowledge and understanding of the basic constitutional rights and the pedagogical implications presented in teaching students at institutions of higher education, the intended purpose of this article is to address those issues.

Success, efficiency, and proficiency in certain occupations require familiarity with US Constitutional rights more than other occupations. For example, although a journeyman plumber is required to know building codes related to plumbing, knowledge of constitutional rights is not necessary to be a successful plumber. Also, the importance of understanding how the law is interpreted, applied, and recorded in a liberal arts curriculum serves a broader purpose of which is essential due to the pervasiveness of the law in our society. (Lader, 1973 p. 148).

Do undergraduate university students understand the fundamental rights and responsibilities afforded by the U.S. Constitution? More specifically, what do young adults studying criminal justice actually know about their rights under the Bill of Rights? Average Americans (those without specific legal training) are inundated by legal "advice" through television sitcoms, reality television, courts, or perhaps personal experience and/or direct observation of the court system. To what extent does knowledge of the Bill of Rights impact workplace decisions? Some non-legal professions may require more familiarity of specific rights under the Bill of Rights than others, however, only professionals working in the criminal justice fields have the authority under the color of law which is backed by the force of the state to restrict the liberty and freedom of individuals within their respective jurisdiction.

This article will not serve as a mechanism to provide an analysis of court decisions of which interpret the applicability of the Constitution, but rather will provide valuable insight into the overall implications regarding the knowledge, or lack thereof, of students majoring in criminal justice relative to the rights afforded under the United 
States Constitution.

\subsection{Describe Relevant Scholarship}

With the exception of Lader (1973), the scholarly literature is silent on published accounts of the extent of knowledge of specific constitutional rights of American undergraduate university students, and equally so regarding the knowledge of rights of collegiate students. Generally, the study of law in the United States is limited to professional schools, however, recently a renewed interest in undergraduate legal education has been revived in a few liberal arts curriculums (Lader, 1973 p. 126).

To help fill that void in the literature, we have surveyed undergraduate students at one public university situated in the Great Lakes region of the United States whom have a declared major of criminal justice to determine what these students know about specific constitutional rights as relevant to the criminal justice career field.

\subsection{The First Amendment}

\section{"Amendment I}

Congress shall make no law respecting an establishment of religion, or prohibiting the free exercise thereof; or abridging the freedom of speech, or of the press; or the right of the people peaceably to assemble, and to petition the government for a redress of grievances" (U.S. Const. Amend. I).

Criminal justice students do enjoy the same protection as other students and the general public under the First Amendment. However, upon entering their careers in the criminal justice system and unlike most other professions, although the fundamental right to the freedom speech afforded to all is not abridged, public speech may be limited in a profound manner due to the political environment in which criminal justice professionals work in furtherance of executing their duty to protect and serve the public. Most high-ranking criminal justice officials (e.g. Chiefs of Police, Sheriffs, County Prosecutors, etc.) secure their positions through appointment by elected officials or in the alternative are officials elected by the citizenry of the jurisdiction served. To clearly illustrate this point, it is well-known by professionals working in the criminal justice system that publicly endorsing any candidate seeking to be elected by the citizenry for an elected office could result in career limiting consequences in the event the opponent of the endorsed candidate prevails in the election. While the Constitution prohibits a government employer from discharging or demoting an employee because the employee supports a particular political candidate there are exceptions which would allow prohibitions against employees participating in partisan activity if such a policy furthers the effectiveness of the agency in providing the service (Heffernan v. City of Paterson, New Jersey, et al., 2016).

Until the present study, scholarly studies have not been reported relative to the topic of criminal justice majors' knowledge, understanding and ability to articulate and apply the First Amendment in a manner that is or will be relevant when they enter their careers in the criminal justice professions.

\subsection{The Fourth Amendment}

"Amendment IV

The right of the people to be secure in their persons, houses, papers, and effects, against unreasonable searches and seizures, shall not be violated, and no warrants shall issue, but upon probable cause, supported by oath or affirmation, and particularly describing the place to be searched, and the persons or things to be seized." (U.S. Const. amend. IV).

Most Americans know that in the event law enforcement obtains evidence, such as compelling a suspect to confess, without offering the Miranda warning is a violation of the rights afforded under the Fifth Amendment of the United States Constitution, however, few Americans understand that the Miranda warning is dependent upon custodial interrogation. (Miranda v. Arizona, 1966). It is required that law enforcement have probable cause to take an individual into custody. The courts have drawn a bright line in defining custody, essentially, it is a custodial situation when a person does not believe that they are free to leave or that their freedom has been restricted in a significant manner (e.g. back seat of a squad car with the doors locked, in an interview room at the stationhouse to which access is thorough locked doors, etc.). Often, questioning suspects by law enforcement personnel may begin as non-custodial, however, may quickly become custodial as probable cause becomes apparent to the law enforcement personnel. Because particularized knowledge or training is not required to understand that a violation of the Fourth Amendment by criminal justice professionals e.g. law enforcement or their agent (those working under their direction) is a violation of rights afforded under the United States Constitution. What does require particularized knowledge and training are the mechanics of the exclusion of evidence under the Fruit of the Poisonous Tree Doctrine of the Exclusionary Rule, (Weeks v. United States, 1914). It is critical that students majoring in the field of 
criminal justice possess a firm understanding of the applicability of the rights afforded under the Fourth Amendment of the United States Constitution and the circuitous connection of the amendments.

Traditionally, criminal justice professionals have been held in high regard and have enjoyed respect simply by virtue of the position of authority possessed, however, the unquestionable respect and even authority has been challenged by current societal norms and the culture of accountability through transparency created by social media and the internet of which permits instant review, availability and disseminating news events by those on the scene during the event via cell phone cameras and other instantaneous recording applications on personal electronic devices.

The court of public opinion is often convened prior to gathering all relevant facts and information by the criminal justice professionals delegated to perform unbiased investigations in the quest for truth seeking. Thus, the burden of proof requirements placed on criminal justice professionals relative to the defense against alleged violations of the fourth amendment rights of individuals receives scrutiny at unprecedented levels.

Until the present study, scholarly studies have not been reported relative to the topic of criminal justice majors' knowledge, understanding and ability to articulate and apply the Fourth Amendment in a manner that is or will be relevant when they enter their careers in the criminal justice professions.

\subsection{The Tenth Amendment}

"Amendment X

The powers not delegated to the United States by the Constitution, nor prohibited by it to the states, are reserved to the states respectively, or to the people." (U.S. Constitution, Amendment X).

The importance of the Tenth Amendment to future criminal justice professionals is fundamentally important to criminal justice majors relative to understanding the role of the federal government in making and influencing policies as they may affect the state and local levels of government and those within the respective jurisdictions. To what extent can the federal government dictate policies to the states and local units of government, to what extent can the federal government influence criminal justice laws applicable to the states and political subdivisions, and to what extent are states bound by federal policy and influence? This amendment directly affects criminal justice professionals in that often, federal policies and/or laws are directly tied to the federal funding of specific initiatives of which is particularly enticing to the states to comply with the promulgated at the federal level. Also, the United States operates under a dual court system of which allows the criminal prosecution of violations associated with state and federal laws concurrently and/or consecutively without violating the double jeopardy clause of the Fifth Amendment of the United States Constitution.

Until the present study, scholarly studies have not been reported relative to the topic of criminal justice majors' knowledge, understanding and ability to articulate and apply the Tenth Amendment in a manner that is or will be relevant when they enter their careers in the criminal justice professions.

\subsection{The Fourteenth Amendment}

\section{Amendment XIV}

Section 1.

All persons born or naturalized in the United States, and subject to the jurisdiction thereof, are citizens of the United States and of the state wherein they reside. No state shall make or enforce any law which shall abridge the privileges or immunities of citizens of the United States; nor shall any state deprive any person of life, liberty, or property, without due process of law; nor deny to any person within its jurisdiction the equal protection of the laws.

Section 2.

Representatives shall be apportioned among the several states according to their respective numbers, counting the whole number of persons in each state, excluding Indians not taxed. But when the right to vote at any election for the choice of electors for President and Vice President of the United States, Representatives in Congress, the executive and judicial officers of a state, or the members of the legislature thereof, is denied to any of the male inhabitants of such state, being twenty-one years of age, and citizens of the United States, or in any way abridged, except for participation in rebellion, or other crime, the basis of representation therein shall be reduced in the proportion which the number of such male citizens shall bear to the whole number of male citizens twenty-one years of age in such state. 
Section 3.

No person shall be a Senator or Representative in Congress, or elector of President and Vice President, or hold any office, civil or military, under the United States, or under any state, who, having previously taken an oath, as a member of Congress, or as an officer of the United States, or as a member of any state legislature, or as an executive or judicial officer of any state, to support the Constitution of the United States, shall have engaged in insurrection or rebellion against the same, or given aid or comfort to the enemies thereof. But Congress may by a vote of two-thirds of each House, remove such disability.

Section 4.

The validity of the public debt of the United States, authorized by law, including debts incurred for payment of pensions and bounties for services in suppressing insurrection or rebellion, shall not be questioned. But neither the United States nor any state shall assume or pay any debt or obligation incurred in aid of insurrection or rebellion against the United States, or any claim for the loss or emancipation of any slave; but all such debts, obligations and claims shall be held illegal and void.

Section 5 .

The Congress shall have power to enforce, by appropriate legislation, the provisions of this article. (U.S. Const. amend. XIV).

Should all persons in the United States have the right to legal counsel prior to the commencement of custodial interrogation? Should all persons in the United States have the right to due process under the United States Constitution? Should all persons in the United States persons have the right to a trial? Although, these are questions of which require court interpretation in the application of the Constitution, all encounters begin with law enforcement and/or agents of the government, therefore, student knowledge and understanding of the Fourteenth Amendment is critical to ensure that students whom will be working in the criminal justice field properly execute the duties inherent in their respective criminal justice professions.

Until the present study, scholarly studies have not been reported relative to the topic of criminal justice majors' knowledge, understanding and ability to articulate and apply the Fourteenth Amendment in a manner that is or will be relevant when they enter their careers in the criminal justice professions.

\subsection{The Fifteenth Amendment}

"Amendment XV

Section 1.

The right of citizens of the United States to vote shall not be denied or abridged by the United States or by any State on account of race, color, or previous condition of servitude.

Section 2.

The Congress shall have power to enforce this article by appropriate legislation.” (U.S. Const. amend. XV).

State criminal and civil laws are enacted by legislators elected by citizens of the state. The federal criminal code is enacted by Congress with advisory opinions offered by various department heads appointed by and serve at the pleasure of the President of the United States confirmed by the United States Senate. The President, members of Congress as well as Senators are all elected officials. Although, laws and rules are enacted by public officials, it is critical that criminal justice students whom will be working in the criminal justice field properly execute the duties inherent in their respective criminal justice professions. For example, in today's political climate there are groups which monitor polling stations and criminal justice professionals must be able to distinguish between legitimate activity and activity which interferes with $15^{\text {th }}$ Amendment rights.

Until the present study, scholarly studies have not been reported relative to the topic of criminal justice majors' knowledge, understanding and ability to articulate and apply the Fifteenth Amendment in a manner that is or will be relevant when they enter their careers in the criminal justice professions.

\subsection{State Hypotheses and Their Correspondence to Research Design}

Hypothesis one: There will be no difference between pre-survey scores compared to post-survey scores on confidence in ability to give a typical situation or issue of the First Amendment in the context of criminal justice.

Hypothesis two: There will be no difference between pre-survey scores compared to post-survey scores on confidence in ability to give a typical situation or issue of the Fourth Amendment in the context of criminal justice. 
Hypothesis three: There will be no difference between pre-survey scores compared to post-survey scores on confidence in ability to give a typical situation or issue of the Tenth Amendment in the context of criminal justice.

Hypothesis four: There will be no difference between pre-survey scores compared to post-survey scores on confidence in ability to give a typical situation or issue of the Fourteenth Amendment in the context of criminal justice.

Hypothesis five: There will be no difference between pre-survey scores compared to post-survey scores on confidence in ability to give a typical situation or issue of the Fifteenth Amendment in the context of criminal justice.

Hypothesis six: There will be no difference between pre-survey aggregate scores compared to post-survey aggregate scores on confidence in ability to give a typical situation or issue for the First, Fourth, Tenth, Fourteenth, and Fifteenth amendments of the U.S. Constitution in the context of criminal justice.

\section{Method}

\subsection{Recruitment}

Undergraduate students majoring in criminal justice with the career goal of working in criminal justice professions (licensed and non-licensed positions) were recruited to participate in the study involving one lower level, but not an introductory criminal justice course and three upper division criminal justice courses across four academic semesters. Acceptance into the criminal justice program/department is based upon admittance into the university, however, students must have a cumulative grade point average of at least 2.25 (out of 4.00) to graduate from the program. Students desirous of licensed positions within the criminal justice professions (e.g. licensed peace officers) are required to successfully complete specific courses of which deem students eligible by the state licensing authority of peace officers to sit for the state licensure examination.

\subsection{Participant (Subject) Characteristics}

Undergraduate students majoring in criminal justice at this university are typically first-generation, traditional students. However, an increasing number of students are professionals currently working in criminal justice professions whom are required to have an earned Bachelor of Science degree to be eligible for promotion within their respective agencies, or are completing military service. Although the university admits both international students as well as students from across the United States, the majority of the students at the university are from the Great Lakes region of the United States.

\subsection{Sampling Procedures}

A convenient sample of undergraduate students majoring in criminal justice over four semesters were recruited to participate in the study. Participants were required to sign informed consent forms informing them of their right to anonymity, their right to withdraw without penalty, and assurance that participation or not will not have an effect on their course grade. No incentives were given for participation in this study, however, all participants were enrolled in the course in which the survey questionnaire was administered. Eighty-one (81) students over four semesters participated this study. Of those, the surveys of 41 students were discarded due to lack of clear identification on some aspect of the survey for pairing purposes, resulting in 40 matched pairs of surveys being used for the analysis. The convenient sample of these students are typical of undergraduate criminal justice majors enrolled in this university, and are assumed typical of American students enrolled in similar criminal justice courses at public universities across the United States. We assume an alpha level of .05, we assume that sufficient evidence of rank differences in groups if the p-value is less than .05 , and we assume that the responses to each of the five survey questions for each part were independent.

\subsection{The Questionnaire}

The pre-survey and post-survey questionnaires were identical. Each questionnaire had two sections. The first section asked participants to rate their confidence in being able to explain one typical example to each of the five constitutional amendments (First, Fourth, Tenth, Fourteenth, and Fifteenth). The participants rated their confidence on a Likert scale from 1 ("No Confidence) to 4 ("Very Confident"). The second part of the questionnaire instructed the participant to write one typical example of each of the amendments rated in the first part of the questionnaire. The questionnaire was validated by Lawshe's content validity method (Lawshe, 1974). Test-retest reliability was built into the questionnaire by asking respondents to first rate their confidence on the ability to give a typical situation or issue relevant to each amendment, then give a typical example relevant to the amendment. 


\subsection{Research Design}

A survey design was used and followed the methodology in Boynton and Greenhalgh (Boynton, 2004). A convenient sample of undergraduate students majoring in criminal justice were solicited to participate in several criminal justice courses for criminal justice majors. The experimental treatment was attendance and completion of the criminal justice course in which the pre-survey and post-survey were conducted.

\section{Results}

Table 1. Descriptive Statistics for Likert Scale Responses to Pre-survey and Post-survey Responses

\begin{tabular}{|c|c|c|c|c|c|}
\hline & Min & Median & Mode & $\operatorname{Max}$ & Range \\
\hline $\begin{array}{lc}\text { First } & \text { amend. } \\
\text { Pre-survey Results }\end{array}$ & 1 & 3 & 3 & 4 & 3 \\
\hline $\begin{array}{l}\text { First amend. } \\
\text { Post-survey Results }\end{array}$ & 2 & 3 & 3 & 4 & 2 \\
\hline $\begin{array}{l}\text { Fourth amend. } \\
\text { Pre-survey Results }\end{array}$ & 1 & 3 & 3 & 4 & 3 \\
\hline $\begin{array}{l}\text { Fourth amend. } \\
\text { Post-survey Results }\end{array}$ & 2 & 3 & 3 & 4 & 2 \\
\hline Tenth amend. & & & & & \\
\hline Pre-survey Results & 1 & 1 & 1 & 4 & 3 \\
\hline $\begin{array}{l}\text { Tenth amend. } \\
\text { Post-survey Results }\end{array}$ & 1 & 2 & 1 & 4 & 3 \\
\hline $\begin{array}{l}\text { Fourteenth amend. } \\
\text { Pre-survey Results }\end{array}$ & 1 & 2 & 3 & 4 & 3 \\
\hline $\begin{array}{l}\text { Fourteenth amend. } \\
\text { Post-survey Results }\end{array}$ & 1 & 3 & 3 & 4 & 3 \\
\hline $\begin{array}{l}\text { Fifteenth amend. } \\
\text { Pre-survey Results }\end{array}$ & 1 & 2 & 3 & 4 & 3 \\
\hline $\begin{array}{l}\text { Fifteenth amend. } \\
\text { Post-survey Results }\end{array}$ & 1 & 3 & 3 & 4 & 3 \\
\hline $\begin{array}{l}\text { Aggregate Pre-survey } \\
\text { results }\end{array}$ & 7 & 12 & 13 & 18 & 11 \\
\hline $\begin{array}{l}\text { Aggregate Post-survey } \\
\text { results }\end{array}$ & 9 & 15 & 15 & 20 & 11 \\
\hline
\end{tabular}

Descriptive statistics (min, median, mode, max, and range) for ordinal data pre-survey and post-survey results on participant level of confidence of being able to give a typical situation or issue for the First, Fourth, Tenth, Fourteenth, and Fifteenth U.S. Constitution Amendments and aggregate scores (sum of amendment scores). 
Table 2. Results of Wilcoxon Signed-Rank test on Confidence in Understanding of Constitutional Amendments

\begin{tabular}{llll}
\hline & $\mathrm{Z}$ & $\mathrm{p}$-value & Effect Size \\
\hline First amend. & -2.23 & $*<.026$ & .25 \\
Fourth amend. & -2.26 & $*<.008$ & .25 \\
Tenth amend. & -2.49 & $*<.013$ & .28 \\
Fourteenth amend. & -3.00 & $*<.003$ & .34 \\
Fifteenth amend. & -2.38 & $*<.02$ & .26 \\
Aggregate & -4.01 & $*<.0001$ & .45
\end{tabular}

Pre-survey scores were compared with post-survey scores using the Wilcoxon Signed-Rank test. The Wilcoxon Signed-Rank test critical value, $\mathrm{Z}$, the p-value with respect to alpha $=.05$, and the effect size for each of the five pre-survey and post-survey questions for each amendment and the aggregate score (sum of amendment scores) on participant level of confidence of being able to give a typical situation or issue for the First, Fourth, Tenth, Fourteenth, and Fifteenth U.S. Constitution Amendments. “*” indicates significance at the alpha .05 level.

\subsection{Statistics and Data Analysis}

Hypothesis one: There will be no difference between pre-survey scores compared to post-survey scores on confidence in ability to explain the First Amendment.

There is sufficient evidence to reject the null hypothesis at the .05 alpha level and accept the alternative hypothesis that there is a statistically significant difference $(\mathrm{p}<.026)$ between pre-survey and post-survey scores for confidence in the ability to give a relevant example for the First Amendment. The effect size (.25) indicates a small difference between the scores. The median and the mode for the pre-survey were both 3, as were the post-survey median and mode scores.

Hypothesis two: There will be no difference between pre-survey scores compared to post-survey scores on confidence in ability to explain the Fourth Amendment.

There is sufficient evidence to reject the null hypothesis at the .05 alpha level and accept the alternative hypothesis that there is a statistically significant difference $(p<.008)$ between pre-survey and post-survey scores for confidence in the ability to give a relevant example for the Fourth Amendment. The effect size (.25) indicates a small difference between the score. The median and the mode for the pre-survey were both 3, as were the post-survey median and mode scores.

Hypothesis three: There will be no difference between pre-survey scores compared to post-survey scores on confidence in ability to explain the Tenth Amendment.

There is sufficient evidence to reject the null hypothesis at the .05 alpha level and accept the alternative hypothesis that there is a statistically significant difference $(\mathrm{p}<.013)$ between pre-survey and post-survey scores for confidence in the ability to give a relevant example for the Tenth Amendment. The effect size (.28) indicates a small difference between the score. The median and the mode for the pre-survey were both 1, while the post-survey median was 2 and the mode was 1 .

Hypothesis four: There will be no difference between pre-survey scores compared to post-survey scores on confidence in ability to explain the Fourteenth Amendment.

There is sufficient evidence to reject the null hypothesis at the .05 alpha level and accept the alternative hypothesis that there is a statistically significant difference $(\mathrm{p}<.003)$ between pre-survey and post-survey scores for confidence in the ability to give a relevant example for the Fourteenth Amendment. The effect size (.34) indicates a small difference between the scores. The pre-survey median and mode were both one 1 , while the post-survey median was 2 and the mode was 1.

Hypothesis five: There will be no difference between pre-survey scores compared to post-survey scores on confidence in ability to explain the Fifteenth Amendment.

There is sufficient evidence to reject the null hypothesis at the .05 alpha level and accept the alternative hypothesis that there is a statistically significant difference $(p<.0001)$ between pre-survey and post-survey scores for confidence in the ability to give a relevant example for the Fifteenth Amendment. The effect size (.45) indicates a 
moderate difference between the scores. The median for the pre-survey was 2 and the mode was 3 , while the post-survey median and mode were both 3 .

\subsection{A Pre-survey written responses}

In the pre-survey, 34 of the 40 surveys (85\%) had one or more variations of "IDK", "I don't Know", "I don't remember", a blank, irrelevant, or unintelligible response on one or more questions. Nineteen respondents indicated a confidence score of greater than 1 in part 1 with a corresponding blank example in part 2 the pre-survey.

\section{First Amendment emergent themes included:}

Of the 40 pre-surveys completed, 2 surveys (5\%) listed an irrelevant, unintelligible, or blank example for this amendment. Of those responses that were not irrelevant, unintelligible, or blank, the following themes were identified: freedom of speech and peaceful protest, freedom of religion and the limits of free speech is not inclusive of all speech e.g. "can't yell fire in a movie theater." One respondent gave a score of greater than 1 in part 1 with a blank example in part 2 of the pre-survey.

Fourth Amendment emergent themes included:

Of the 40 pre-surveys completed, 3 surveys (7.5\%) listed an irrelevant, unintelligible, or blank example for this amendment. Of those responses that were not irrelevant, unintelligible, or blank, the following themes were identified: warrants cannot be secured without probable cause, warrants are required and unreasonable searches and seizures are prohibited. Three respondents gave a score of greater than 1 in part 1 with a blank example in part 2 of the pre-survey.

Tenth Amendment emergent themes included:

Of the 40 pre-surveys completed, 34 surveys (85\%) listed an irrelevant, unintelligible, or blank example for this amendment. Students did not provide written responses which illustrated a theme. Of those responses that were not irrelevant, unintelligible, or blank, the following themes were identified: . Nine respondents gave a score of greater than 1 in part 1 with a blank example in part 2 of the pre-survey.

Fourteenth Amendment emergent themes included:

Of the 40 pre-surveys completed, 10 surveys (25\%) listed an irrelevant, unintelligible, or blank example for this amendment. Of those responses that were not irrelevant, unintelligible, or blank, the following themes were identified: everyone is treated equally under the law, everyone has a right to a fair trial and the requirement of due process. Three respondents gave a score of greater than 1 in part 1 with a blank example in part 2 of the pre-survey.

Fifteenth Amendment emergent themes included:

Of the 40 pre-surveys completed, 15 surveys (37.5\%) listed an irrelevant, unintelligible, or blank example for this amendment. Of those responses that were not irrelevant, unintelligible, or blank, the following themes were identified: right to vote. Three respondents gave a score of greater than 1 in part 1 with a blank example in part 2 of the pre-survey.

\subsection{B Post-survey written responses}

In the post-survey, 29 of the 40 surveys (73\%) had one or more variations of "IDK”, "I don't Know", "I don't remember", a blank, irrelevant, or unintelligible response on one or more questions. Twelve post-survey respondents gave a score greater than 1 in part 1 with a corresponding blank example in part 2.

First Amendment emergent themes included:

Of the 40 post-surveys completed, no surveys $(0 \%)$ listed an irrelevant, unintelligible, or blank example for this amendment. Of those responses that were not irrelevant, unintelligible, or blank, the following themes were identified: right to protest $\mathrm{v}$. unlawful assembly, the line is drawn between protesting and unlawful assembly when belligerent an annoying behavior is threatening to others and freedom of religion. No respondents gave a score greater than 1 in part 1 with a blank example in part 2 of the post survey.

\section{Fourth Amendment emergent themes included:}

Of the 40 post-surveys completed, 1 survey (2.5\%) listed an irrelevant, unintelligible, or blank example for this amendment. Of those responses that were not irrelevant, unintelligible, or blank, the following themes were identified: searches and seizures of property, vehicles, home and person, warrants must be issued of which offers protection against illegal searches and seizures. One respondent gave a score greater than 1 in part 1 with a blank example in part 2 of the post survey. 
Tenth Amendment emergent themes included:

Of the 40 post-surveys completed, 25 surveys (62.5\%) listed an irrelevant, unintelligible, or blank example for this amendment. Of those responses that were not irrelevant, unintelligible, or blank, the following themes were identified: federal law over state law, uphold the U.S. Constitution while also laws of your state, state laws cannot conflict with federal laws, states being able to enact their own laws. Ten respondents gave a score greater than 1 in part 1 with a blank example in part 2 of the post survey.

Fourteenth Amendment emergent themes included:

Of the 40 post-surveys completed, 1 surveys (2.5\%) listed an irrelevant, unintelligible, or blank example for this amendment. Of those responses that were not irrelevant, unintelligible, or blank, the following themes were identified: keeping someone from their due process of the law, being arrested and having the right to a lawyer, must see a judge within a reasonable amount of time after being arrested, proper treatment while in custody, right to due process. No respondents gave a score greater than 1 in part 1 with a blank example in part 2 of the post survey.

Fifteenth Amendment emergent themes included:

Of the 40 post-surveys completed, 7 surveys (17.5\%) listed an irrelevant, unintelligible, or blank example for this amendment. Of those responses that were not irrelevant, unintelligible, or blank, the following themes were identified: the right to vote is not dependent upon race, can't vote if you are convicted of a felony, voting is a privilege so long as you meet the requirements, whether an offender has the right to vote. One respondent gave a score greater than 1 in part 1 with a blank example in part 2 of the post survey. 
Table 3. Comparison of Meaningful Responses by Amendment and Comparison of Blank examples with scores greater than 1

\begin{tabular}{|c|c|c|c|c|}
\hline & $\begin{array}{lr}\text { Number of } & \text { Blank, } \\
\text { Irrelevant, } & \text { or } \\
\text { Unintelligible } & \\
\text { Responses out of } 40\end{array}$ & $\begin{array}{l}\text { Scores Greater than } 1 \\
\text { in Part } 1 \text { of the } \\
\text { Questionnaire with } \\
\text { Corresponding Blank } \\
\text { Example in Part } 2\end{array}$ & $\begin{array}{l}\text { Percent of Blank, } \\
\text { Irrelevant, } \\
\text { Unintelligible } \\
\text { Responses out of } 40\end{array}$ & $\begin{array}{l}\text { Scores Greater than } 1 \\
\text { in Part } 1 \text { of the } \\
\text { Questionnaire with } \\
\text { Corresponding Blank } \\
\text { Example in Part } 2\end{array}$ \\
\hline $\begin{array}{l}1^{\text {st }} \text { amend. } \\
\text { Pre-survey }\end{array}$ & 2 & - & $5 \%$ & $2.5 \%$ \\
\hline $\begin{array}{l}1^{\text {st }} \text { amend. } \\
\text { Post-survey }\end{array}$ & 0 & 0 & $0 \%$ & $0 \%$ \\
\hline $\begin{array}{l}4^{\text {th }} \text { amend. } \\
\text { Pre-survey }\end{array}$ & 3 & 3 & $7.5 \%$ & $7.5 \%$ \\
\hline $\begin{array}{l}4^{\text {th }} \text { amend. } \\
\text { Post-survey }\end{array}$ & 1 & 1 & $2.5 \%$ & $2.5 \%$ \\
\hline $\begin{array}{l}10^{\text {th }} \text { amend. } \\
\text { Pre-survey }\end{array}$ & 34 & 9 & $85 \%$ & $22.5 \%$ \\
\hline $\begin{array}{l}10^{\text {th }} \text { amend. } \\
\text { Post-survey }\end{array}$ & & & & \\
\hline & 25 & 10 & $62.5 \%$ & $25 \%$ \\
\hline $\begin{array}{l}14^{\text {th }} \text { amend. } \\
\text { Pre-survey }\end{array}$ & 10 & 3 & $25 \%$ & $7.5 \%$ \\
\hline $\begin{array}{l}14^{\text {th }} \text { amend. } \\
\text { Post-survey }\end{array}$ & & & & \\
\hline & 1 & 0 & $2.5 \%$ & $0 \%$ \\
\hline $\begin{array}{l}15^{\text {th }} \text { amend. } \\
\text { Pre-survey }\end{array}$ & 15 & 3 & $37.5 \%$ & $7.5 \%$ \\
\hline $\begin{array}{l}15^{\text {th }} \text { amend. } \\
\text { Post-Survey }\end{array}$ & & & & \\
\hline & 7 & 1 & $17.5 \%$ & $0 \%$ \\
\hline
\end{tabular}

Pre-survey and post-survey written response comparisons of the number and percentages of blank, irrelevant, or unintelligible responses. Participants were asked to write a relevant example of each of the listed amendments of the U.S. Constitution in both the pre-survey and post-survey.

3.3 Participant Flow

Participants were enrolled in one lower level, but not an introductory criminal justice course and three upper division criminal justice courses across four academic semesters. None of the participants repeated the courses, however, a few students were enrolled concurrently in the upper division criminal justice courses. Some participants did not take 
both pre-survey and post surveys due to course scheduling conflicts at the beginning of the semester. All students enrolled in the criminal justice courses surveyed were exposed to the Amendments of the Constitution included in the survey as a significant portion of the curriculum and coursework throughout the semesters

\section{Discussion}

\subsection{General Observations}

Because the use of discretion during the execution of duties performed by criminal justice professionals is significant, especially by those whom are first to respond to calls for service (e.g. law enforcement), it is critical that they have a firm understanding of the rights afforded under the United States Constitution, and the applicability of the Amendments while executing the duties and responsibilities their positions. Although our criminal justice system is based upon substantive and procedural due process whereas remedies are available to correct errors, the liability of errors have proven quite costly on many levels, including, but not limited to, protracted litigation, monetary sanctions to departments/agencies, professionals as individuals, erosion of public trust, credibility of departments/agencies as well as the individual professional. The effect of the violation upon the victim has the potential to be profound through stigmatization, labeling, loss of gainful employment and the repercussions associated with loss of income and the loss of liberty and freedom. The effect upon the community and society may also be profound in that the loss of trust in the criminal justice system and the professionals whom are entrusted to perform specific duties may result in diminishing effectiveness, civil unrest, public safety and a negative impact to commerce.

It is expected that upon graduation from the university and passing the licensure examination that students entering criminal justice professions will possess the skills, ability and knowledge to competently perform the duties entrusted to them without error or violation of rights, laws and rules.

The determination of what criminal justice undergraduate students understand/know about specific rights afforded under the First, Fourth, Tenth, Fourteenth, and Fifteenth Amendments of United States Constitution is an essential first-step for educators in higher education in refining effective pedagogy to meet the academic needs of undergraduate students to enable their professional success upon graduation from the university and entry into their respective criminal justice professions.

We used the collective pre-survey scores as an overall view of the confidence of students understanding of the five amendments. The pre-survey aggregated median score of 12 out of 20 with a mode of 13 , indicated that students had a moderate understanding of the amendments in the contextual application to criminal justice with a moderate confidence level of their ability to provide an example as indicated by the mode (on the Likert scale of a value of 1 of which a self-report of no confidence to a self-reported value of 4 self-reporting high confidence).

The post-survey aggregated score of 15 out of 20 with a mode of 15, indicated a slight increase in the students' understanding of the amendments in the contextual application to criminal justice with an increase in their confidence level to provide an example as indicated by the mode. The increased confidence level can be attributed to a greater understanding of the amendments in context with their major of criminal justice and their ability to articulate typical situations and issues relevant to the specific amendments in a manner that they did not seem prepared or confident to articulate at the beginning of the semester in the pre-survey. The effect size between the pre-survey aggregate scores compared to the post-survey aggregate scores was moderate. In spite of coming in to class with an apparently solid grounding in terms of confidence to explain typical situations or events relevant to the individual amendments, they did develop an apparent greater confidence in the ability to give examples. We interpret this gain in confidence as a reflection of deeper understanding of these amendments though completing this course.

\subsection{The First Amendment}

The pre-survey and post-survey results do not indicate a change or variation in the median confidence scores, however, the blank response rate decreased from $5 \%$ on the pre-survey to $0 \%$ blank responses when asked to provide a relevant example on the post-survey. Because all students were able to provide a relevant example on the post-survey, a shift in the students' confidence was exhibited in the ability to articulate a relevant example illustrates an alignment in the level of the self-reported confidence at the beginning of the semester to that realized at the end of the semester as evidenced in the post-survey. Although, the examples provided in the pre-survey were relevant, the examples were generalized and non-specific. The examples provided in the post-survey demonstrated analysis of which illustrated critical thinking and a conceptualized understanding of the First Amendment as applicable in the situations they may encounter in their future careers in their respective criminal justice professions. For example, public speech today can be accomplished through mediums not available two decades ago, therefore, providing 
students with relevant and contemporary examples enhances their ability to understand, articulate and apply principles of the First Amendment.

\subsection{The Fourth Amendment}

The pre-survey and post-survey results do not indicate a change or variation in the median confidence scores, however, the blank response rate decreased 5\% from the pre-survey and post-surveys (from $7.5 \%$ on the pre-survey to $2.5 \%$ post-survey) when asked to provide a relevant example on the post-survey. Because most students were able to provide a relevant example on the post-survey, a moderate increase in the ability of students to articulate a relevant example illustrates a shift in alignment of their level of the self-reported confidence at the beginning of the semester to that realized at the end of the semester as evidenced in the post-survey. Although, the examples provided in the pre-survey were relevant, the examples were generalized and non-specific. The examples provided in the post-survey demonstrated analysis of which illustrated critical thinking and a conceptualized understanding of the Fourth Amendment as applicable to the situations they may encounter in their future careers in their respective criminal justice professions. The students were exposed to the Fourth Amendment in the classroom through discussions and assigned reading more than for the First, Tenth, Fourteenth, and Fifteenth Amendments, therefore, the enhanced understanding manifested by their ability to provide relevant examples at the end of the semester in the post-survey is not surprising.

\subsection{The Tenth Amendment}

The pre-survey and post-survey results indicate a slight change in the median confidence scores of which is consistent with the overall rates of confidence self-reported. What is surprising is the rate of difference associated with the blank response rate of which decreased from $85 \%$ on the pre-survey to $62.5 \%$ blank responses when asked to provide a relevant example on the post-survey. Because significantly more students $(22.5 \%)$ were able to provide a relevant example on the post-survey in comparison to the pre-survey, an emerging shift in the students' ability to articulate a relevant example illustrates greater understanding of the Tenth Amendment of which will serve them well as they advance to the higher level law courses in the criminal justice department. The examples provided in the pre-survey were relevant, however, were generalized and non-specific. The examples provided in the post-survey demonstrated analysis of which illustrated critical thinking and a conceptualized understanding of the Tenth Amendment as applicable to the situations they may encounter in their future careers in their respective criminal justice professions. Because the student perception that this amendment is not directly applicable to professionals working in the criminal justice system at the state level, it is reasonable to conclude that the increase many be attributable to criminal justice undergraduate students interested in pursuing careers in the criminal justice system at the federal level as the relationship between the federal and state levels of government is appealing and of interest to them. Unexpectedly, ten questionnaires had a confidence score greater than 1 in part one and a corresponding blank in part 2 in the post-survey compared to just nine such scores in the pre-survey. Because the number of questionnaires with this situation were very close to being equal in the pre-survey and post-survey, we are not alarmed at the increase, but we are concerned with the relatively greater number of such responses in comparison to such responses for the other amendments. It is apparent that something did not click with the students with respect to the Tenth amendment in the context of criminal justice. As noted above, the likely explanation is simply that this amendment does not seem as applicable in practice to students at this point.

\subsection{The Fourteenth Amendment}

The pre-survey and post-survey results indicate a slight change in the median confidence scores of which is consistent with the overall rates of confidence self-reported. Similar to the results associated with the $10^{\text {th }}$ Amendment, what is surprising is the rate of difference associated with the blank response rate of which decreased from $25 \%$ on the pre-survey to $2.5 \%$ blank responses when asked to provide a relevant example on the post-survey. Because significantly more students $(22.5 \%)$ were able to provide a relevant example on the post-survey in comparison to the pre-survey, a shift in the students' ability to articulate an on-point example illustrates greater overall understanding of the Fourteenth Amendment. The examples provided in the pre-survey were generalized and non-specific with the examples provided in the post-survey demonstrating higher level thinking, however, the depth of the answers provided to the post-survey relative to this amendment in comparison to the First and Fourth Amendments illustrates that a different pedagogical approach is required stress the importance of this amendment as it relates to criminal justice professionals. 


\subsection{The Fifteenth Amendment}

The pre-survey and post-survey results indicate a slight change in the median confidence scores of which is consistent with the overall rates of confidence self-reported. Similar to the results associated with the $14^{\text {th }}$ Amendment, the rate of difference is surprising associated with the blank responses from the pre and post surveys. The rate decreased from $37.5 \%$ on the pre-survey to $17.5 \%$ blank responses (20\% difference) when asked to provide a relevant example on the post-survey. Because significantly more students $(20 \%)$ were able to provide a relevant example on the post-survey in comparison to the pre-survey, similar to the results illustrated in the $14^{\text {th }}$ Amendment, a shift in the students' ability to articulate an on-point example illustrates greater overall understanding of the Fifteenth Amendment. The examples provided in the pre-survey were generalized and non-specific with the examples provided in the post-survey demonstrating higher level thinking, however, the depth of the answers provided to the post-survey relative to this amendment in comparison to the First and Fourth Amendments illustrates that a different pedagogical approach is required stress the importance of this amendment as it relates to criminal justice professionals.

\subsection{Pedagogical Implications}

The data suggests that the self-reported confidence level of criminal justice students and their actual ability to cite relevant examples is directly proportional to the amendments that they believe are applicable to them as individuals as well as those that will be relevant to them professionally. In consideration of the results of this study from a holistic perspective, student analytics and application of the amendments would result in an on par alignment in confidence as well as the ability to provide a relevant example across all amendments if students are given assignments and group activities that require the application of the amendments that criminal justice professionals are reasonably expected to encounter during the execution of the duties and responsibilities entrusted to them to perform. For example, today social media is wrestling with the limits of free speech v. hate speech, expectations of privacy in public places and when/where we may encounter searches, e.g. sporting events, theaters, schools, public buildings, etc. Providing relevant examples to students in the classroom enhances their understanding, knowledge and applicability of constitutional rights.

\subsection{Conclusion}

Students preparing at the university level will be expected to understand and apply the legal doctrines and theories associated with the current court cases related to the rights afforded under the United States Constitution upon entering their professions in the criminal justice system. At this public university, to ensure the competent execution of the duties of which they will be entrusted to perform and to meet the licensing requirements, students majoring in criminal justice are required to successfully complete numerous specific courses based upon the law. It is important to note that constitutional law is included as a part of the curriculum in each of the law based courses required in the criminal justice major at this public university.

Because there is a significant gap in scholarly literature regarding student knowledge of the basic and fundamental rights afforded under the United States Constitution (and the landmark court cases) we performed a study of students majoring in criminal justice at our public university situated in the Great Lakes region of the United States. We administered a pre-instruction and post-instruction questionnaire designed to measure the confidence level, knowledge and understanding of the amendments to the extent that students had the ability to articulate, in writing, a relevant example pertaining to the First, Fourth, Tenth, Fourteenth, and Fifteenth Amendments of the U.S. Constitution.

The outcome of the survey study provides important insight relative to the effectiveness of instructional pedagogy in a scholarship of teaching framework for undergraduate students majoring in criminal justice. Although it is important to note that the results of this survey were based upon the results from one university, it is likely that the results would be consistent across colleges and universities with similar curriculums and academic requirements. It should also be noted that prudence should be exercised in the comprehensive application of the results of this survey to all students, at all institutions of higher education because the course content and curriculum are significant variables of which may produce markedly different outcomes.

\section{Acknowledgements}

We thank our students for their participation in this study.

We also thank Dr. Derek Webb, Bemidji State University who provided consultation regarding the statistical methodology for this article. 


\section{References}

Boynton, P. M., \& Greenhalgh, T. (2004). Selecting and developing your questionnaire. BMJ, 328(7451), $1312-1315$. https://doi.org/10.1136/bmj.328.7451.1312

Call, I. \& O'Brien, J. (2011). Secondary preservice teachers' knowledge of the first amendment. Teacher Education Quarterly, 115-133.

Coggins, III P.E. \& Heuer, J. (forthcoming). Teacher Education Majors' Basic Knowledge of U.S. Constitutional Rights and Pedagogical Implications. International Research in Higher Education.

Garcetti v. Ceballos, 547 U.S. 410 (U.S. Supreme Court 2006).

Hazelwood School District v. Kuhlmeier, 484 U.S. 260 (U.S. Supreme Court 1988).

Heffernan v. City of Paterson, New Jersey, et al., 136 S. Ct. 1412 (U.S. Supreme Court 2016).

Lader, P. (1973, January 1). Experiments in undergraduate legal education: The teaching of law in the liberal arts curriculum of American colleges and universities. Journal of Legal Education, 25, 125-214.

Lawshe, C. (1974). A quantitative approach to content validity. Personnel Psychology, 28(4), 563-575. https://doi.org/10.1111/j.1744-6570.1975.tb01393.x

Miranda v. Arizona, 384 U.S. 436 (U.S. Supreme Court 1966).

Pell, S. (1994). Preservice teachers' lack of knowledge about educational law: Ignorance is no excuse. Illinois School Quarterly, 14(4) 138-150.

Weeks v. United States, 232 U.S. 393 (U.S. Supreme Court 1914). 